\title{
5. STRONTIUM-ISOTOPE STRATIGRAPHY OF LOWER CRETACEOUS ATOLL CARBONATES IN THE MID-PACIFIC MOUNTAINS ${ }^{1}$
}

\author{
Hugh C. Jenkyns, ${ }^{2}$ Charles K. Paull, ${ }^{3}$ David I. Cummins, ${ }^{2}$ and Paul D. Fullagar ${ }^{3}$
}

\begin{abstract}
Strontium-isotope ratios of Cretaceous shallow-water carbonates from two guyots in the Mid-Pacific Mountains are compared with high-resolution data derived from stratigraphically well-calibrated belemnites and oysters from sequences in England. The thickest section penetrated on Resolution Guyot can, with the aid of carbon-isotope data, be divided into stages ranging from uppermost Hauterivian to the Albian/Cenomanian boundary. The section on Allison Guyot, although more ambiguous in interpretation, is exclusively Albian, and its upper limit is also close to the contact with the Albian/Cenomanian boundary. Comparison of age-vs.-thickness data on the two guyots suggests that Allison was subsiding at a rate at least twice that of Resolution Guyot during the Albian. The strontium-isotope data are compatible with the hypothesis of synchronous cessation of deposition of shallow-water carbonates at both sites.
\end{abstract}

\section{INTRODUCTION}

Strontium-isotope stratigraphy is founded on three guiding principles (Burke et al., 1982; Palmer and Elderfield, 1985; Elderfield, 1986). First, it is assumed that the ${ }^{87} \mathrm{Sr} /{ }^{86} \mathrm{Sr}$ ratio in sea water always has been, as it is at present, homogenous throughout the oceans, this being a consequence of the long residence time of strontium compared to the short mixing times of oceanic water masses. Second, it is assumed that the ${ }^{87} \mathrm{Sr} /{ }^{86} \mathrm{Sr}$ ratio has varied systematically throughout geological time. And third, it is assumed that this isotopic ratio has been accurately recorded by calcium-bearing minerals precipitated from seawater. The modern ${ }^{87} \mathrm{Sr} /{ }^{86} \mathrm{Sr}$ ratio of 0.7092 is primarily determined by the balance between radiogenic $\mathrm{Sr}$ delivered to the oceans by rivers weathering and draining the continents $\left({ }^{87} \mathrm{Sr} /{ }^{86} \mathrm{Sr} \approx\right.$ 0.7119 ), and nonradiogenic $\mathrm{Sr}\left({ }^{87} \mathrm{Sr} /{ }^{86} \mathrm{Sr} \approx 0.7035\right.$ ) supplied to the oceans through ocean-ridge and other hydrothermal systems (Palmer and Edmond, 1989). A buffering effect is produced by the return, into the oceans, of old marine strontium from dissolution or recrystallization of carbonate sediments and limestones. To date, most illustrations and applications of strontium-isotope stratigraphy have dealt with sediments deposited during the last $75 \mathrm{~m}$.y. As the Tertiary ${ }^{87} \mathrm{Sr} /{ }^{86} \mathrm{Sr}$ curve is steep and calibrated vs. stratigraphically well-dated deep-sea sequences (e.g., Burke et al., 1982; DePaolo and Ingram, 1985; DePaolo, 1986; Hess et al., 1986; Hodell et al., 1991), age-resolution of an unknown section to 0.3 to $3 \mathrm{~m}$.y. is attainable. Using the strontium-isotope curve derived from DSDP sites as a reference, the Tertiary stratigraphy of shallow-water atoll carbonates in the Pacific Ocean and adjacent seas can be considerably refined (Ludwig et al., 1988; Quinn et al., 1991; Ohde and Elderfield, 1992). This technique is of particular value for shallow-water carbonates whose sparse benthic faunas allow only limited stratigraphic resolution. Remarkably, perhaps, the meteoric-water diagenesis supposedly so characteristic of shallow-water carbonates generally has been insignificant enough or conservative enough to ensure that original ${ }^{87} \mathrm{Sr} /{ }^{86} \mathrm{Sr}$ ratios were preserved during lithification of many samples. Departures from this ideal situation are recognized by isotopic values that plot away from a consistent trend defined by the majority of data points.

'Winterer, E.L., Sager, W.W., Firth, J.V., and Sinton, J.M. (Eds.), 1995. Proc. ODP, Sci. Results, 143: College Station, TX (Ocean Drilling Program).

${ }^{2}$ Department of Earth Sciences, University of Oxford, Parks Road, Oxford, OX1 3PR. United Kingdom.

${ }^{3}$ Geology Department, University of North Carolina at Chapel Hill, Chapel Hill, NC, 27599-3315, U.S.A.
Such aberrant samples presumably record a history of stratigraphic redistribution of $\mathrm{Sr}$ from overlying younger to underlying older sediments consequent upon subaerial exposure (Quinn et al., 1991).

For the Cretaceous, however, particularly the early to middle interval of the period, the ${ }^{87} \mathrm{Sr} /{ }^{86} \mathrm{Sr}$ reference curve is poorly defined. The studies of Burke et al. (1982) and Koepnick et al. (1985) showed a decline through the Barremian, to reach a minimum ${ }^{87} \mathrm{Sr} /{ }^{86} \mathrm{Sr}$ ratio less than 0.70730 close to the Aptian/Albian boundary, followed by a rise up toward the Cenomanian. However, the spread of data points in this curve is such that its use as a dating tool for the Early to midCretaceous would barely give resolution to the stage level.

The more recent determinations of Jones et al. (1994), using stratigraphically well-calibrated oysters and belemnites from the Lower and mid-Cretaceous of England, better define this critical interval, even though there is a lack of data points around the Aptian/Albian boundary (Fig. 1). The zonal scheme is based on ammonites from the northern European province. The data clearly indicate a rise through the Valanginian that continues through the Hauterivian, to reach a peak in the mid-Barremian with a ${ }^{87} \mathrm{Sr} /{ }^{86} \mathrm{Sr}$ ratio of 0.70750 , followed by a decline to a minimum around the Aptian/Albian boundary $\left({ }^{87} \mathrm{Sr} /{ }^{86} \mathrm{Sr}\right.$ ratio of 0.70730 or less). This is followed by a subsequent rise to a peak in the mid- to late Albian $\left({ }^{87} \mathrm{Sr} /{ }^{86} \mathrm{Sr}\right.$ ratio $\left.=0.70745\right)$, a minor fall, then an upward trend through to the end of the stage (Fig. 1). Using this curve as a reference enables one to fix the approximate positions of the Barremian/Aptian and Aptian/Albian boundaries in Site 866 (Resolution Guyot: Fig. 2) with reasonable confidence and also helps one date the Albian section cored in Site 865 (Allison Guyot: Fig. 2).

Because changes in ${ }^{87} \mathrm{Sr} /{ }^{86} \mathrm{Sr}$ isotopic ratios of Lower Cretaceous atoll carbonates are so subtle, analytical and normalization techniques become critical if the data are to have stratigraphic value when compared with a reference curve. Hence, the techniques used in this study are described in some detail.

\section{MATERIAL AND SAMPLE SELECTION}

Limestone samples were collected at regular intervals, wherever recovery permitted, throughout the shallow-water sections cored at Site 866 (Resolution Guyot) and Site 865 (Allison Guyot). A number of limitations, however, need to be borne in mind. Where recovery was particularly poor, as in the upper part of both sections, the possibility exists for stratigraphic mis-assignment as a result of caving. In addition, subaerial diagenesis would have operated throughout deposition of many of the facies, as witnessed by the local presence of molds of formerly aragonitic fossils, the occurrence of bird's-eyes, 


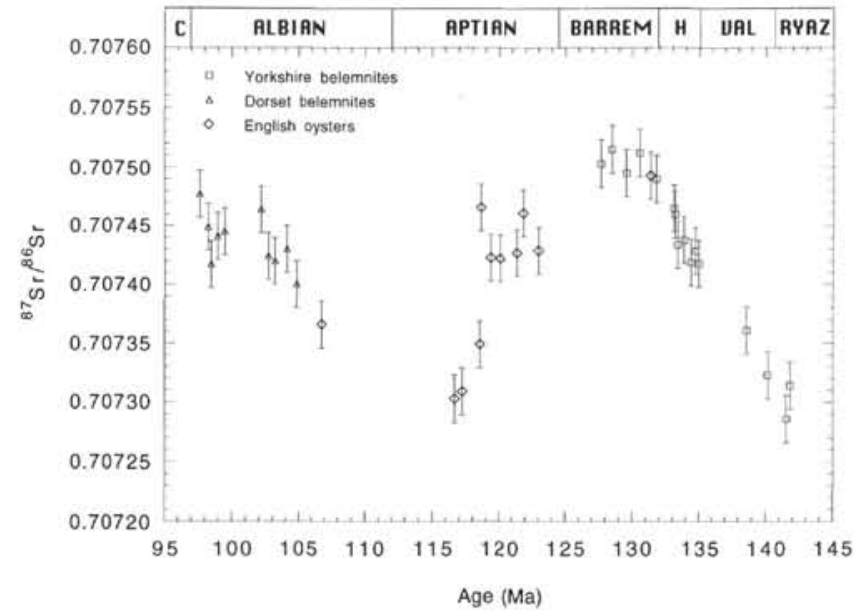

Figure 1. Sr-isotope reference curve for the Early Cretaceous derived from fossiliferous material collected from well-dated outcrops in England. Data have been renormalized to NBS $987=0.710260$. Normalization procedures described in text. Errors quoted as $\pm 20 \times 10^{-6}$ for all analyses. Data from Jones (1992) and Jones et al. (1994). Time scale is that of Harland et al. (1990).

and distinct calcrete horizons. Many of the subaerial interludes during which these lithologic features were generated probably were brief enough to avoid large-scale redistribution of strontium, but there is no way of quantifying the importance of this effect. Those lithologies whose carbon- and oxygen-isotopic ratios are relatively negative, however, can be identified as having suffered appreciable meteoricwater diagenesis (see Quinn et al., 1991).

At Site 866, from a depth of $790 \mathrm{~m}$ downward, dolomite was detected in the cores; initially only in small centimeter-scale zones, but in deeper levels becoming more pervasive, locally constituting the total rock type. Dolomite, however, is all but absent in the oolitic grainstone directly overlying basalt. At Site 865 , from a depth of $660 \mathrm{~m}$ downward, dolomite also was detected. Wherever possible, dolomitic material has been avoided during sampling, because such material may not carry a pristine ${ }^{87} \mathrm{Sr} /{ }^{86} \mathrm{Sr}$ ratio. Lithologies obviously containing substantial amounts of clay, presumably carrying its own characteristic ${ }^{87} \mathrm{Sr} /{ }^{86} \mathrm{Sr}$ signature, also have been scrupulously avoided. Other samples whose isotopic values are compromised are those in proximity to basaltic basement, which may have incorporated foreign strontium with low ${ }^{87} \mathrm{Sr} /{ }^{86} \mathrm{Sr}$ ratios during diagenesis (Koepnick et al., 1985). These limitations essentially mean that the lower $700 \mathrm{~m}$ of the core from Site 866 give data that are less reliable than those derived from the upper kilometers. Geochemical and cathodoluminescence data from Site 865 suggest that contamination from basalt may possibly extend more than $100 \mathrm{~m}$ into the carbonate section above the sills that constitute the base of the hole (Röhl et al., this volume).

\section{STRONTIUM-ISOTOPE ANALYSES}

All samples received in the Oxford laboratory initially were cleaned thoroughly to remove any possible adhering detritus and obvious late-stage vein sparite. They then were washed thoroughly with distilled water by ultrasonic treatment for at least $20 \mathrm{~min}$. Dilute acid $(0.6 \mathrm{M} \mathrm{HCl})$ was added to the samples to cause slight external etching, with ultrasonic treatment again used for another $10 \mathrm{~min}$. After rinsing and drying, the samples were crushed to a fine powder with mortar and pestle, before addition of further dilute acid $(0.3 \mathrm{M} \mathrm{HCl})$, followed by ultrasonic treatment for 10 min more. During crushing, samples preferentially fracture along any diagenetic veins, which are then exposed to attack from the second batch of acid and should be removed as a potential contaminant. Sufficient material from the dried sample powders was weighed out into vials to ensure that $>50 \mathrm{mg}$ of $\mathrm{Sr}$ was taken into solution after $4 \mathrm{~mL}$ of $2.5 \mathrm{M} \mathrm{HCl}$ had been added to the vials. To

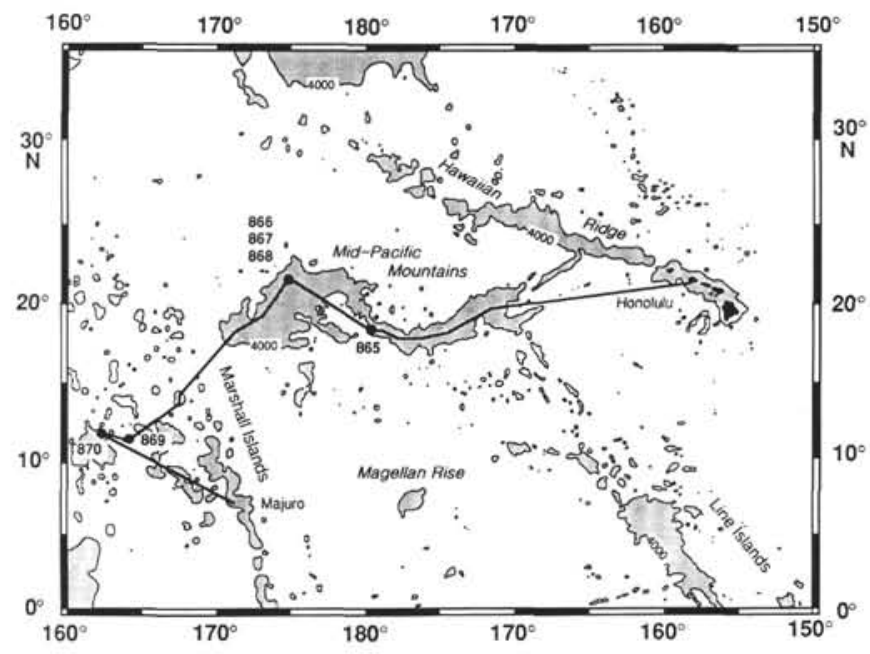

Figure 2. Map of portion of the Pacific Ocean, illustrating location of drillsites cored during Leg 143. Site 866 is the deep site drilled on Resolution Guyot. Site 865 is situated on Allison Guyot.

remove any insoluble (terrigenous?) contaminant, the $4 \mathrm{~mL}$ of solution was centrifuged (at $\sim 3000 \mathrm{rpm}$, for $10 \mathrm{~min}$ ), and $1 \mathrm{~mL}$ of the clear solute was then loaded onto the prepared $\mathrm{Sr}$ columns.

Twelve identical quartz columns were filled with $5 \mathrm{~mL}$ of a standard cation exchange resin. Elution curves for $\mathrm{Sr}^{2+}$ and $\mathrm{Ca}^{2+}$ revealed that a good separation between the two cations was possible with just one single passage through the resin. The required elute was collected in clean vials and placed under evaporator lamps until nearly dry. The solutions then were transferred to precleaned small quartz tubes, along with a drop of aqua regia, which ensured that any remaining organic matter was destroyed. All contents were evaporated to a solid residue. Prepared samples were loaded onto thoroughly washed and degassed, single tantalum-ribbon, Cathodeon beads to remove any dirt impurities. To aid volatilization, $1 \mathrm{~mL}$ of $0.25 \mathrm{M} \mathrm{H}_{3} \mathrm{PO}_{4}$ initially was loaded and dried upon the filament. The samples were redissolved in $\sim 2 \mathrm{~mL}$ of distilled water and redried upon the filament at a current of $\sim 1.5 \mathrm{~A}$.

Isotopic analyses were performed using a modified and updated VG 54E mass spectrometer, situated in the Department of Earth Sciences, Oxford University. Data collection was controlled by the computer program Analyst written by Ken Ludwig (USGS, Denver, Open-file Report 92-543). Isotopic ratios were collected with the major ${ }^{88} \mathrm{Sr}$ peak focused to give a beam size of between 6.5 and $7.5 \times$ $10^{-11} \mathrm{~A}$ on the single-collecting Keithley Head. Analyses were continued for 20 blocks or until the overall isotopic ratio reached its required precision level, whichever came sooner. A minimum number of 10 blocks of data ensured that the final quoted isotopic ratio was the average of at least 200 individual measurements. The target $\mathrm{Sr}$ precision level was $\pm 14 \times 10^{-6}$, lying well within the external precision $\left(\sim \pm 20 \times 10^{-6}\right) . A 1{ }^{87} \mathrm{Sr} /{ }^{86} \mathrm{Sr}$ values have been given together with a $2 \sigma$ error about the overall mean value. All ${ }^{87} \mathrm{Sr} /{ }^{86} \mathrm{Sr}$ ratios have been internally corrected for fractionation by renormalizing to a ${ }^{86} \mathrm{Sr} /{ }^{88} \mathrm{Sr}$ ratio $=0.1194$. At least one filament in every carousel of 14 samples was loaded with a 1000-ppm Sr solution of the NBS 987 standard.

At the University of North Carolina, rock and samples remaining after pore waters had been squeezed from them (squeeze cakes) were processed in the following way. Specimens were shaved with a knife to remove the possibly contaminated exterior, and any dolomitic or clay-rich material was carefully avoided, as was late-stage vein calcite; then about 5 to $10 \mathrm{mg}$ of rock or squeeze cake was placed in a $7-\mathrm{mL}$ vial. After weighing, ${ }^{84} \mathrm{Sr}$ spike was added to all samples. One milliliter of $1 \mathrm{M}$ acetic acid prepared from ultra-pure acetic acid was added to each sample, and the vials were placed on a hot plate for 30 to 60 $\mathrm{min}$. If the resulting solutions were not clear after cooling, they were centrifuged for $10 \mathrm{~min}$; solutions were then evaporated to dryness. 
A Sr-concentrate was obtained from the samples by ion chromatographic techniques, using a crown ether cation exchange resin $(\mathrm{SrSpec})$. The sample residue was redissolved with approximately 250 $\mathrm{mL}$ of $5 \mathrm{M} \mathrm{HNO}_{3}$. The ion exchange columns were prepared by placing about $75 \mathrm{~mL}$ of cleaned $\mathrm{SrSpec}$ resin in water in each of the small polypropylene columns that were used. The fluid was drained, and the resin washed several times with 2 to $3 \mathrm{~mL}$ water. The resin in each column was conditioned with approximately $750 \mathrm{~mL}$ of $5 \mathrm{M} \mathrm{HNO}_{3}$, which was passed through the columns. The sample was loaded onto the column in approximately $250 \mathrm{~mL}$ aliquots of $5 \mathrm{~N} \mathrm{HNO}_{3}$, and the acid allowed to drain. About $300 \mathrm{~mL}$ of $5 \mathrm{M} \mathrm{HNO}_{3}$ was passed through the column, and this step was repeated three times. The $\mathrm{Sr}$ fraction of the sample then was collected in a vial by passing $500 \mathrm{~mL}$ water through the column, and then collecting another $500 \mathrm{~mL}$ water in the same vial. One microliter of $1 \mathrm{M} \mathrm{H}_{3} \mathrm{PO}_{4}$ was added to each sample, and the solution dried on a hot plate. This technique resulted in good separation of $\mathrm{Sr}$ from $\mathrm{Ca}$, as well as from other cations. To avoid possible contamination of subsequent samples, the resin was used only once.

The prepared samples were dissolved in $1 \mathrm{~mL}$ of $1 \mathrm{M} \mathrm{H}_{3} \mathrm{PO}_{4}$ and loaded onto degassed Ta filaments, which were heated at a current of 1.5 A to dry the samples. The samples were analyzed using a VG Sector 54 thermal ionization mass spectrometer (TIMS) at the Department of Geology, University of North Carolina at Chapel Hill. Up to 20 samples and/or standards were loaded into the sample carousel at one time. Data were obtained using the dynamic multicollection mode of analysis, with computer software provided by VG. Conditions were specified so that the ${ }^{88} \mathrm{Sr}$ peak corresponded to an ion beam of about $4 \times 10^{-11}$ A. Ten blocks of isotopic ratios were obtained, and the final average was based on at least 200 measurements of each isotope. Within-run precision expressed as standard error for the normalized ${ }^{87} \mathrm{Sr} /{ }^{86} \mathrm{Sr}$ ratios usually was $\pm 14 \times 10^{-6}(2 \sigma)$.

\section{NORMALIZATION PROCEDURES}

The analytical software has a built-in correction procedure for the inevitable isotopic fractionation that occurs when the element is volatilized from the filament. Simultaneous with the making of every individual ${ }^{87} \mathrm{Sr} /{ }^{86} \mathrm{Sr}$ measurement, a ${ }^{86} \mathrm{Sr} /{ }^{88} \mathrm{Sr}$ ratio is recorded. The degree of fractionation is then compared to the commonly accepted ${ }^{86} \mathrm{Sr} /{ }^{88} \mathrm{Sr}$ standard $=0.1194$. In common with most other laboratories across the world, an exponential fractional relationship was assumed at Oxford and North Carolina for correcting the analyzed ${ }^{87} \mathrm{Sr} /{ }^{86} \mathrm{Sr}$ ratio. Machine normalization ensures that any variation in ${ }^{87} \mathrm{Sr} /{ }^{86} \mathrm{Sr}$ documented between different samples cannot be the result of analytical artifacts, but reflects primary differences in the fluids that were responsible for precipitation of the original $\mathrm{CaCO}_{3}$.

To facilitate comparison of strontium-isotope data among different laboratories across the world, and also to ensure that the Oxford $54 \mathrm{E}$ and North Carolina Sector 54 mass spectrometers did not produce biased data, at least one standard $\mathrm{Sr}$ solution was incorporated into every carousel made up for $\mathrm{Sr}$ isotopic analysis. In this study, the NBS 987 standard was used, with its long-term average being determined as $0.710260 \pm 20$ at Oxford and $0.710250 \pm 22$ at North Carolina, which compares favorably with values quoted from other laboratories.

Two different ways are available of checking for and, if necessary, correcting for possible biasing of the analyzed data that may have been introduced by natural machine (or other) variations. These are discussed in turn below.

1. In an ideal laboratory having minimal humidity, temperature, and other environmental fluctuations, an ideal mass spectrometer should, with replicate runs of the same sample, give values that show a normal distribution about a long-term average. Any analysis that gives an isotopic value for that standard lying outside the expected limits should be regarded as "suspicious," and all samples rerun in a separate carousel. Other sample data can be accepted at face value, without resorting to any renormalization of data. All differences in replicate isotopic ratios can be explained by natural machine variation. If the long-term value for a particular standard between two laboratories is significantly different, that same difference (assuming a near-linear offset) may be applied to every $\mathrm{Sr}$ isotopic ratio determined by the mass spectrometer that appears to introduce a bias during analysis.

2. Unfortunately, most mass spectrometers do not behave ideally and the laboratories that house them do not conform to an ideal analytical environment, owing to seasonal, and even weekly, variations in humidity and temperature. It is possible that these changes will influence absolute isotopic values. To attempt to correct for this, all of the isotopic data determined during any one run can be renormalized, by determining the offset of the standard sample(s) from accepted published values, and then adding the same correcting constant to all of the $\mathrm{Sr}$ isotopic ratios determined on samples within that same carousel. This technique was employed by Jones (1992) for the Cretaceous determinations used as a reference plot in this study.

However, since Jones' work was performed, the Oxford 54E machine has been significantly more stable and less prone to short-term variation; hence, we have not normalized the data, but simply quoted them at the same time as determining the long-term average of NBS $987=0.710260 \pm 20$. For the samples investigated at North Carolina, three to six standards (NBS 987) were analyzed in each carousel, and the average of these determinations was used to adjust the ${ }^{87} \mathrm{Sr} /{ }^{86} \mathrm{Sr}$ ratios of the unknowns, with 0.710250 being taken as the accepted ratio of the standard. This is essentially the same technique as that adopted by Jones (1992). To correct for the slight mismatch between the values obtained for the NBS 987 standard in the two different laboratories, a value of $10 \times 10^{-6}$ has been added to all of the ${ }^{87} \mathrm{Sr} /{ }^{86} \mathrm{Sr}$ ratios determined at the University of North Carolina.

Jones (1992) used a different isotopic standard (Eimer and Amend) to adjust the values obtained for Cretaceous fossils. The ${ }^{87} \mathrm{Sr} /{ }^{86} \mathrm{Sr}$ ratios for this standard, run by Jones (1992) with the 54E mass spectrometer at Oxford, were routinely higher (mean value $=0.708028$ ) than the routinely quoted figure $(0.708000)$, the value to which his own Eimer and Amend standards, and likewise all samples, were renormalized. During the period that his work was undertaken, the mean value for the NBS 987 standard was 0.710254 . Given that the value for this standard over the period that work on Cretaceous atoll carbonates was conducted averaged 0.710260 , one normalization method would be to add $28+6 \times 10^{-6}=34 \times 10^{-6}$ to the isotopic ratios determined from English Cretaceous macrofossils. However, data from Palmer and Elderfield (1985) and Elderfield (1986) indicate that an Eimer and Amend value of 0.708000 corresponds to ${ }^{87} \mathrm{Sr} /{ }^{86} \mathrm{Sr}$ ratio of 0.710209 for the more common NBS 987 standard, a value for the latter that falls between that quoted by Hess et al. (1986) and that derived from data in Burke et al. (1982). As the value for NBS 987 routinely obtained at Oxford during the period of analysis of the Cretaceous atoll carbonates was 0.710260 , a constant factor of $51 \times 10^{-6}$ was added to the isotopic determinations of English macrofossils to enable a direct comparison to be made among the various data sets.

\section{OTHER ANALYSES AND SAMPLE ELIMINATION}

All limestone samples received in the Oxford laboratory from Sites 866 and 865 were analyzed by X-ray diffraction; only those samples that contained less than a trace of dolomite (estimated as $3 \%$ by comparison with X-ray diffractograms of known dolomite-calcite ratios) were used to assemble the strontium-isotope curve. In addition, the same samples also were analyzed for oxygen- and carbonisotope ratios with a VG Isocarb device and Prism mass spectrometer in the Department of Earth Sciences at Oxford University. Samples from depths greater than $1 \mathrm{~km}$ at Site 866 (Resolution Guyot), ana- 

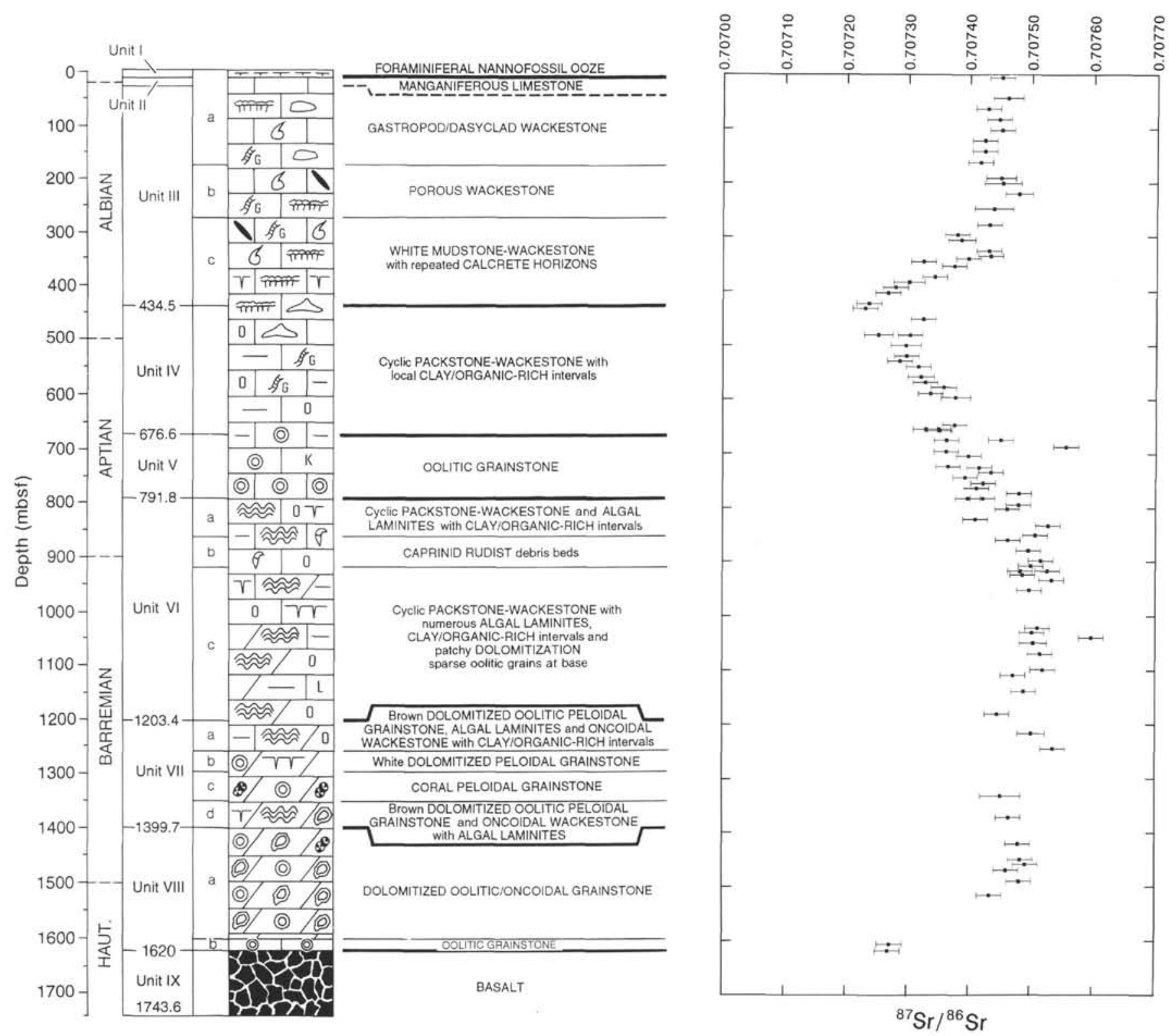

Figure 3. Sr-isotope curve for the section cored at Resolution Guyot; biostratigraphic dating is poor. Only samples containing less than $3 \%$ of dolomite have been included. Oxford data have not been normalized; the long-term average of NBS 987 during the period the analyses were undertaken was 0.710260 . UNC data have been normalized to NBS $987=0.710260$. Error bars shown as $\pm 20 \times 10^{-6}$ for analyses, unless precision was worse than this, in which case the greater value has been given. The ${ }^{87} \mathrm{Sr} /{ }^{86} \mathrm{Sr}$ minimum close to the Aptian/Albian boundary is particularly well displayed. Samples near the basaltic basement clearly have incorporated mantle-derived $\mathrm{Sr}$ and have no stratigraphic significance.

lyzed at the University of North Carolina, were not included in the curve, as their mineralogy is unknown and could include dolomite.

\section{RESULTS: RESOLUTION GUYOT}

The ${ }^{87} \mathrm{Sr} /{ }^{86} \mathrm{Sr}$ data from the section cored at Resolution Guyot (Site 866) are shown in Appendix A and Figure 3. The similarity in trend to the reference curve (Fig. 1) is immediately apparent. Below 1000 mbsf, the data quality deteriorates as (1) dolomitization has affected the carbonate facies, (2) clay-rich lithologies become more abundant, and (3) basal samples lie in close stratigraphic proximity to the basaltic basement. Two analyses from the oolitic grainstone directly overlying basalt have ${ }^{87} \mathrm{Sr} /{ }^{86} \mathrm{Sr}$ ratios that are anomalously low, and presumably incorporated foreign $\mathrm{Sr}$ with a mantle-derived isotopic signature. The dolomites analyzed by Flood and Chivas (this volume), from levels immediately above this, have only slightly higher ratios and equally may carry a geochemical signature of fluid-basement interaction. These results could indicate that the basaltic core of the island was emergent early in the history of the edifice and that fluids, derived from its weathered mantle, found their way into the carbonate cement that encloses the ooids and into early diagenetic dolomite. Alternatively, fluids may have been expelled from the basalts and incorporated into overlying sediment at a later stage. The problem lies in assessing at what level above basement the influence of low-ratio Sr on the overlying carbonate facies is lost.

The Sr-isotope data from the Cretaceous of England, after having been normalized in the preferred manner outlined above, gave values for the Hauterivian that fall between 0.70741 and 0.70749 (Fig. 1). However, if absolute values of ${ }^{87} \mathrm{Sr} /{ }^{86} \mathrm{Sr}$ ratios are to be used for dating purposes, normalization procedures for the reference curve can be- 

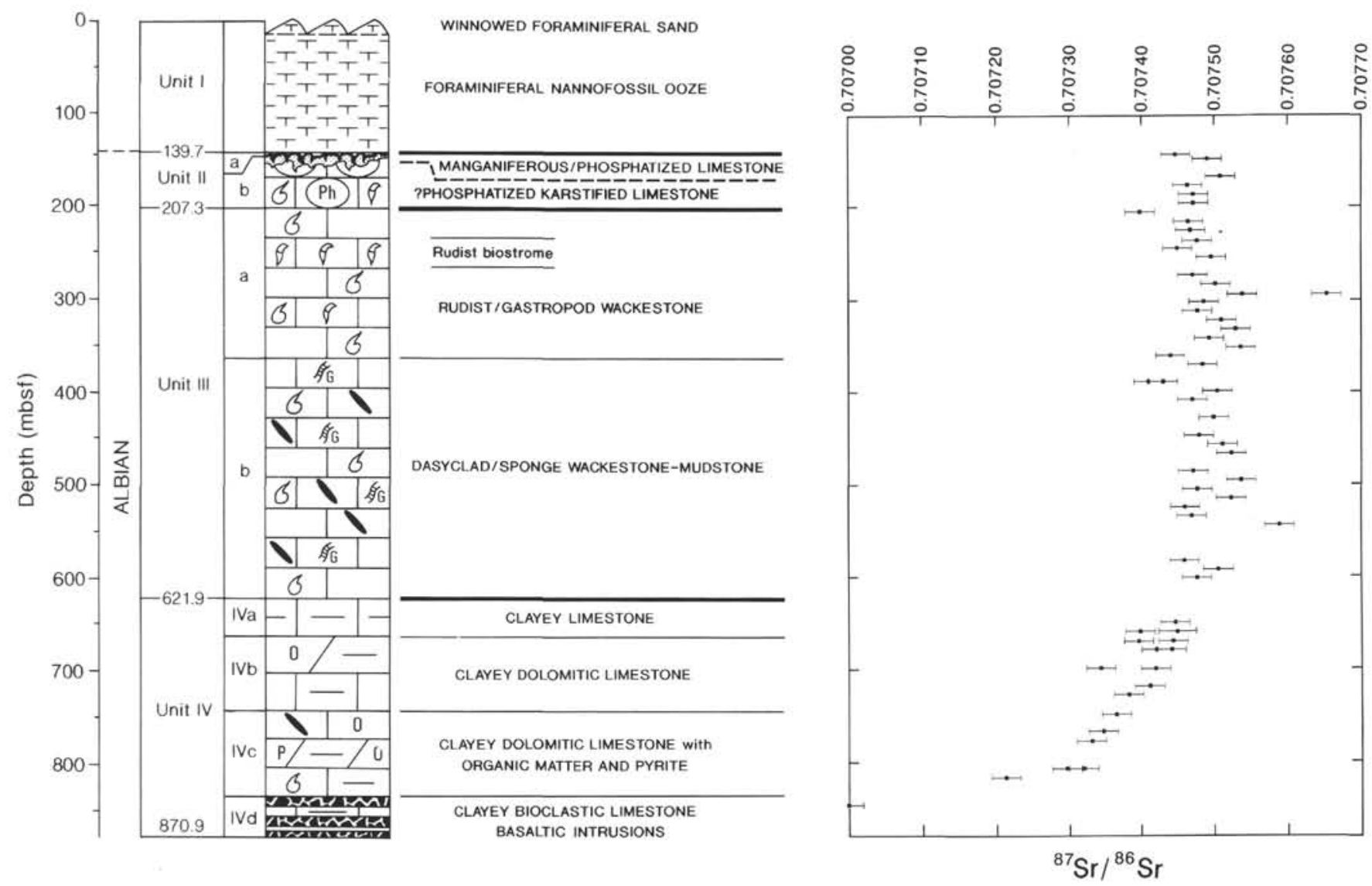

Figure 4. Sr-isotope curve for the section cored at Allison Guyot. Data have been renormalized to NBS $987=0.710260$. Error bars shown as $\pm 20 \times 10^{-6}$ for all analyses, unless precision was worse than this, in which case the greater value has been given. The profile is assumed to have true stratigraphic significance, but pervasive influence of mantle-derived strontium from the basaltic sills at the base of the section cannot be discounted.

come critical. The alternative normalization technique (i.e., adding 34 $\times 10^{-6}$ to the published values of Jones, 1992, and Jones et al., 1994) would give figures of 0.70739 to 0.70747 for the stage. By ignoring the isotopic determinations from the two samples nearest basement at Site 866 (Fig. 3) and by considering the effects of both normalization techniques, the likelihood is that at least the basal $100 \mathrm{~m}$ or so of the section is of Hauterivian age.

Reference to the shape and absolute values of the English Sr-isotope curve further suggests that the Aptian/Barremian boundary should lie between 800 and $900 \mathrm{mbsf}$. The ${ }^{87} \mathrm{Sr} /{ }^{86} \mathrm{Sr}$ trace falls relatively steeply at a sub-bottom depth of about $850 \mathrm{~m}$ and a stratigraphic gap or gaps may be present in this region. The contact between the Aptian and Albian should lie between 400 and 500 mbsf, given that the reference curve, albeit poorly defined for this interval, shows a negative excursion across the stage boundary. Several points plot above the main trend and presumably have incorporated radiogenic Sr during diagenesis, although their oxygen- and carbon-isotope values are in no way extraordinary (Appendix A). The Albian shows no major offsets and, hence, appears tolerably complete up to the end of the stage (i.e., up to the Albian/Cenomanian boundary), with the possibility of a hiatus or hiatuses at about $400 \mathrm{mbsf}$, where a steep rise in the isotopic ratio is seen at levels where repeated calcrete horizons developed.

Comparison of these positions for the stage boundaries with those achieved by carbon-isotope stratigraphy (Jenkyns, this volume) shows a high degree of correspondence. The light-isotope data suggest (1) that the Hauterivian/Barremian boundary is placed in the interval from 1425 to 1500 mbsf; (2) that the Barremian/Aptian stage boundary lies around 900 mbsf; and that (3) the Aptian/Albian stage boundary is situated near $500 \mathrm{mbsf}$. Paleontological data from benthic foraminifers generally are in accord with this division of Cretaceous stages, except for the placing of the Hauterivian/Barremian boundary (ArnaudVanneau and Sliter, this volume).

Absolute-age data for the basement rocks of Resolution Guyot (Pringle and Duncan, this volume) give maximum figures close to $127 \mathrm{Ma}$. Such values would fall in the Barremian with the time scale of Harland et al. (1990), and at the Hauterivian/Barremian boundary in the time scale of Obradovich (1993).

\section{RESULTS: ALLISON GUYOT}

The strontium-isotope stratigraphy of the shallow-water carbonates of Allison Guyot is illustrated in Appendix B and Figure 4. Comparative chemostratigraphy of both guyots, using the same depth scale, is shown in Figure 5. As with Resolution Guyot, clay and dolomite become more abundant in the lower portion of the core, in this case below about $620 \mathrm{mbsf}$. The few points that plot away from a consistent trend are again unexceptional in their carbon- and oxygen-isotope values. The data from Allison Guyot, however, present particular problems of interpretation. The isotopic profile, with its steep rise in ${ }^{87} \mathrm{Sr} /{ }^{86} \mathrm{Sr}$ ratios upward from the base of the hole, compares closely to that of the Albian portion of Resolution Guyot; values of about 0.70720 close to the bottom of the section at Allison Guyot are suggestive of a level close to the Aptian/Albian boundary (Fig. 1). Similar to that at Resolution Guyot, the curve is characterized by a sharp rise in isotopic ratios, which could be related to the presence of a hiatus (or hiatuses), in this case at a depth in the 700 to $800 \mathrm{mbsf}$ range (Fig. 5 ), were this feature not registering a real and rapid chemical change in the oceans. The basal sample (Fig. 4) comes from between basalts (interpreted as intrusive) that are present at the base of the section and clearly has incorporated mantle-derived $\mathrm{Sr}$. The oxygen-isotope val- 

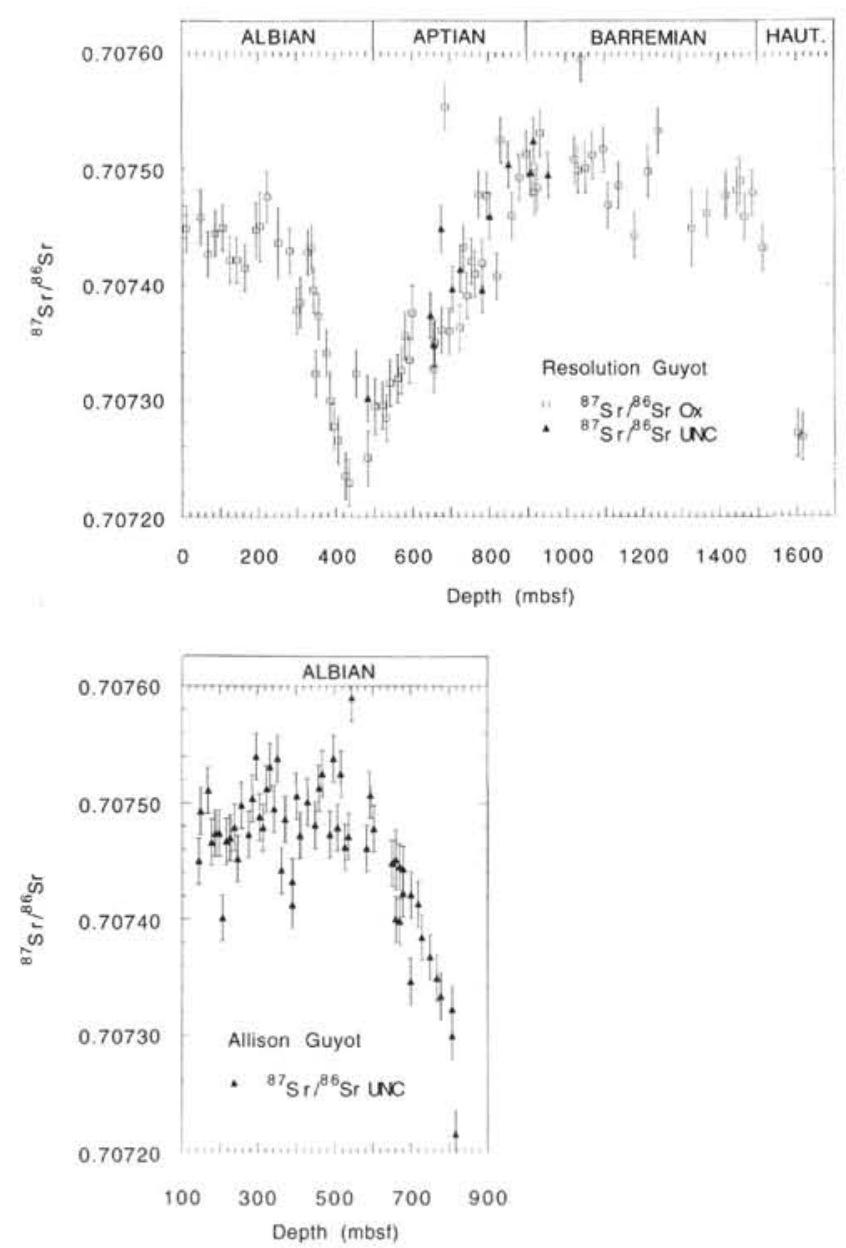

Figure 5. Comparative curves for Allison and Resolution guyots plotted on the same depth scale, indicating the higher Albian sedimentary rates of the former.

ues of this sample are also uncharacteristically light (Appendix B), which could indicate recrystallization at elevated temperatures.

However, unlike the samples from Resolution Guyot, the basal carbonates from Allison Guyot, up to a level of about $680 \mathrm{mbsf}$, display cathodoluminescence; they also contain higher levels of manganese, known to activate this phenomenon, than are found higher in the section (Röhl et al., this volume). Iron and other elements have been enriched over the same stratigraphic interval. If these elements are hydrothermally derived, the possibility exists that the ${ }^{87} \mathrm{Sr} /{ }^{86} \mathrm{Sr}$ signature in carbonates cored from the contact with the sills up to 600 mbsf registers an upward-decreasing enrichment in mantle-derived $\mathrm{Sr}$. The intrusion of sills rather than extrusion of flows, as in Site 866, could have been important for promoting hydrothermal transport of mobile elements. Moreover, a correlation exists between the increase in ${ }^{87} \mathrm{Sr} /{ }^{86} \mathrm{Sr}$ ratios and the presence and abundance of clays: smectites become less important upsection (Sager, Winterer, Firth, et al., 1993).

Initial paleontological determinations suggested that the entire carbonate section on Allison Guyot was of late Albian age (Sager, Winterer, Firth, et al., 1993). However, subsequent finds of benthic and planktonic foraminifers have indicated that the base of the section is of probable late Aptian to early Albian age (Arnaud and Sliter, this volume; Sliter, this volume), entirely in accord with an interpretation of the $\mathrm{Sr}$-isotope ratios as primary. Study of the absolute-age data from the basalts from Allison Guyot, although subject to the uncertainties of elastic time scales, equally suggest the presence of older Albian strata. Ages of $104.9 \pm 2.0$ and $111.1 \pm 1.3 \mathrm{Ma}$ (Pringle and Duncan, this volume) would be placed by all recent time scales securely in the Albian; and Harland et al. (1990) and Obradovich
(1993) suggested an earliest Albian age for the greater figure. Although the basalts have been interpreted as intrusive, they are thought to have been emplaced penecontemporaneously with or just after the deposition of the enclosing clayey bioclastic limestone (Sager, Winterer, Firth, et al., 1993).

Taken together, these three lines of evidence suggest that most of the Albian is represented by the section cored on Allison Guyot. As a caveat, however, note that dating of the English reference section has been based on boreal ammonites, dating of the Allison section on planktonic and benthic foraminifers, and correlation of subdivisions of the Albian using these different schemes is inexact. What does seem likely from a study of the Sr-isotope curve (Figs. 4, 5) and comparison with the English reference section (Fig. 1), is that the top of the carbonate section on Allison Guyot can be dated as being near the Albian/Cenomanian boundary, as is the case on Resolution Guyot. Paleontological data from dredge hauls also suggest that the top of the carbonate section is of latest Albian age, appenninica Zone (Grötsch and Flügel, 1992; Winterer et al., 1993).

Finally, note that the latest Albian Sr-isotope signatures of the carbonates from Allison Guyot are, on average, slightly more radiogenic than those from Resolution Guyot. The significance of this difference, indeed, whether it is real or an analytical artifact, is not clear.

\section{DEPOSITIONAL RATES OF SHALLOW-WATER CARBONATES}

Using the Sr-isotope data illustrated above and $\mathrm{C}$-isotope data (Jenkyns, this volume) to add further refinement, the following suggestions can be made as to positioning the stage boundaries in the shallow-water carbonates of Resolution Guyot: Hauterivian/Barremian at $1500 \mathrm{~m}$; Barremian/Aptian at $900 \mathrm{~m}$; Aptian/Albian at $500 \mathrm{~m}$; and Albian/Cenomanian near the top of the shallow-water carbonate section. On the Harland et al.(1990) time scale, this would give an average sedimentary rate of $82.2 \mathrm{~m} / \mathrm{m}$.y. for the Barremian (duration $7.3 \mathrm{Ma}$ ), $32 \mathrm{~m} / \mathrm{m}$.y. for the Aptian (duration $12.5 \mathrm{Ma}$ ), and $33.3 \mathrm{~m} / \mathrm{m} . \mathrm{y}$. for the Albian (duration $15 \mathrm{Ma}$ ). On the Obradovich time scale (1993), the figures would change to $100 \mathrm{~m} / \mathrm{m}$.y. for the Barremian (duration 6 $\mathrm{Ma}$ ), $44.4 \mathrm{~m} / \mathrm{m}$.y. for the Aptian (duration $9 \mathrm{Ma}$ ), and $37 \mathrm{~m} / \mathrm{m}$.y. for the Albian (duration 13.5 Ma). These sedimentary rates fall in the typical range for Cretaceous carbonate platforms installed on continental margins (Bosscher and Schlager, 1993).

Given that the shallow-water carbonates of the guyot were deposited near mean sea level, it follows that sedimentary thickness closely reflects basement subsidence (with some additional effects from sediment loading and possible eustatic rises in sea level). The sedimentary rates calculated for Resolution Guyot using the Obradovich time scale thus are more consistent with the thermal exponential-decay curve typical of all ocean floor, whether thermally rejuvenated or otherwise (Parsons and Sclater, 1977; Crough, 1978; Johnson and Carlson, 1992). With the uncertainties in both the time scale and the isotopic age assignments and without knowing how much absolute time is represented by the portion of Hauterivian sediments that is present, it is impossible to produce subsidence curves that are anything but approximations (e.g., Fig. 6).

Particularly intriguing is the comparison between the Albian Srisotope curve of Allison Guyot vs. Resolution Guyot (Fig. 5). If both data sets are accepted as having stratigraphic value, then the depositional rate of shallow-water carbonates at Allison Guyot was at least twice that of Resolution Guyot. It follows, therefore, that Allison Guyot was subsiding much more rapidly than Resolution Guyot during the Albian. This might indicate that Allison Guyot is a younger edifice than Resolution Guyot and, indeed, that the basaltic intrusions from the former may be very close to or even effectively represent true volcanic basement. Alternatively, Allison Guyot may have been subjected to thermal rejuvenation and volcanism, with the basalts representing only the final phase, before the onset of rapid subsidence during the Albian. Study of the present-day depths of the two guyots 


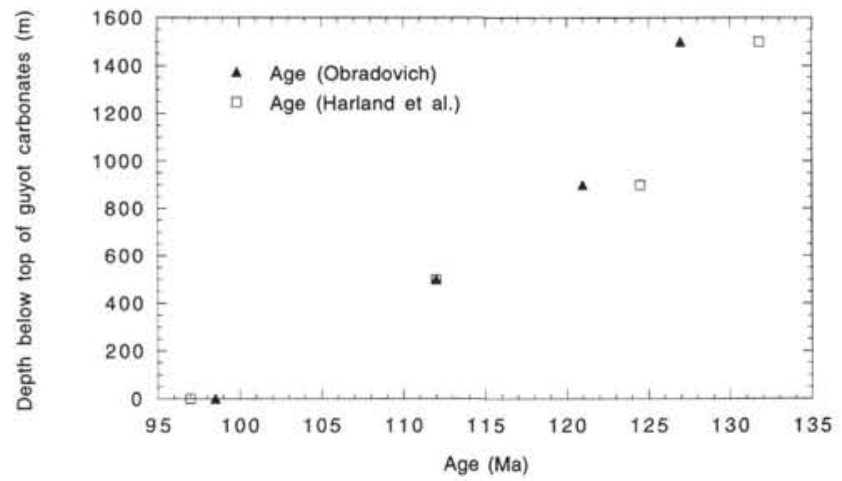

Figure 6. Plot of age vs. depth for Resolution Guyot, using age assignments derived from isotope stratigraphy and both the Harland et al. (1990) and Obradovich (1993) time scales.

or, more appropriately, the depths of the top of the shallow-water carbonates to allow for differential thickness of the pelagic cover, shows that this sedimentary contact lies at $1363 \mathrm{mbsl}$ in the case of Resolution Guyot and $1758 \mathrm{mbsl}$ in the case of Allison Guyot. Thus, after submergence of the carbonate caps, Allison Guyot has continued to subside faster. This is in accord with the regional bathymetric data of Winterer and Metzler (1984), which indicate that the carbonatecapped edifices of the Mid-Pacific Mountains become deeper to the east where the volcanic centers are younger.

\section{CONCLUSIONS}

The results of this study confirm that high-resolution Sr-isotope dating is possible with Mesozoic sequences. Equally, however, it is apparent that more stratigraphically well-constrained analyses will be necessary to create a better-defined Cretaceous reference curve. The absence of data points around the Aptian/Albian boundary is a particularly acute problem, as definition of the stage boundary is not possible with any exactitude at the present time. Nonetheless, given the facies of these guyot carbonates, strontium-isotope stratigraphy does offer comparable or better resolution to that achieved by classical biostratigraphical methods and enables estimates of sedimentary rates to be made. On Resolution Guyot, shallow-water carbonate deposition probably began during the late Hauterivian and continued to Albian/Cenomanian boundary time. During the Albian, Allison Guyot was subsiding and accumulating carbonate at a rate at least twice that of Resolution Guyot. Shallow-water carbonate deposition probably ceased at the same time on both guyots.

\section{ACKNOWLEDGMENTS}

We gratefully acknowledge the help of Roy Goodwin, Steve Wyatt, and Martin Whitehouse in the Oxford Isotope Laboratory, and John Cargill in the North Carolina Isotope Laboratory. Financial support from BP Research to study Mesozoic chemostratigraphy is gratefully acknowledged. Useful reviews were furnished by Ken Ludwig, James Rubenstone, and Will Sager.

\section{REFERENCES*}

Bosscher, H., and Schlager, W., 1993. Accumulation rates of carbonate platforms. J. Geol., 101:345-355.

Burke, W.H., Denison, R.E., Hetherington, E.A., Koepnick, R.B., Nelson, H.F., and Otto, J.B., 1982. Variation of seawater ${ }^{87} \mathrm{Sr} /{ }^{86} \mathrm{Sr}$ throughout Phanerozoic time. Geology, 10:515-519.
Crough, S.T., 1978. Thermal origin of mid-plate hotspot swells. Geophys. J. R. Astron. Soc., 55:451-469.

DePaolo, D.J., 1986. Detailed record of the Neogene Sr isotopic evolution of seawater from DSDP Site 590B. Geology, 14:103-106.

DePaolo, D.J., and Ingram, B.L., 1985. High-resolution stratigraphy with strontium isotopes. Science, 227:938-940.

Elderfield, H., 1986. Strontium isotope stratigraphy. Palaeogeogr., Palaeoclimatol., Palaeoecol., 57:71-90.

Grötsch, J., and Flügel, E., 1992. Facies of sunken Early Cretaceous atoll reefs and their capping late Albian drowning succession (northwestern Pacific). Facies, 27:153-174.

Harland, W.B., Armstrong, R.L., Cox, A.V., Craig, L.E., Smith, A.G., and Smith, D.G., 1990. A Geologic Time Scale 1989: Cambridge (Cambridge Univ. Press).

Hess, J., Bender, M.L., and Schilling, J.G., 1986. Evolution of the ratio of strontium- 87 to strontium- 86 in seawater from Cretaceous to Present. Science, 231:979-984.

Hodell, D.A., Mueller, P.A., and Garrido, J.R., 1991. Variations in the strontium isotopic composition of seawater during the Neogene. Geology, 19:24-27.

Johnson, H.P., and Carlson, R.L., 1992. Variation of sea floor depth with age: a test of models based on drilling results. Geophys. Res. Lett., 19:1971-1974.

Jones, C.E., 1992. The strontium isotopic composition of Jurassic and Early Cretaceous seawater [D. Phil. thesis]. Univ. of Oxford.

Jones, C.E., Jenkyns, H.C., Coe, A.L., and Hesselbo, S.P., 1994. Sr-isotopic variations in Jurassic and Cretaceous seawater. Geochim. Cosmochim. Acta, 58:3061-3074.

Koepnick, R.B., Burke, W.H., Denison, R.E., Hetherington, E.A., Nelson, H.F., Otto, J.B., and Waite, L.E., 1985. Construction of the seawater ${ }^{87} \mathrm{Sr}{ }^{86} \mathrm{Sr}$ curve for the Cenozoic and Cretaceous: supporting data. Chem. Geol. (Isotope Geosci. Sect.), 58:55-81.

Ludwig, K.R., Halley, R.B., Simmons, K.R., and Peterman, Z.E., 1988. Strontium-isotope stratigraphy of Enewetak Atoll. Geology, 16:173-177.

Obradovich, J.D., 1993. A Cretaceous time scale. In Caldwell, W.G.E., and Kauffman, E.G. (Eds.), Cretaceous Evolution of the Western Interior Basin of North America. Spec. Pap. Geol. Assoc. Can., 39:379-396.

Ohde, S., and Elderfield, H., 1992. Strontium isotope stratigraphy of KitaDaito-Jima Atoll, North Philippine Sea: implications for Neogene sea-level change and tectonic history. Earth Planet. Sci. Lett., 113:473-486.

Palmer, M.R., and Edmond, J.M., 1989. The strontium isotope budget of the modern ocean. Earth Planet. Sci. Lett., 92:11-26.

Palmer, M.R., and Elderfield, H., 1985. The $\mathrm{Sr}$ isotopic composition of seawater over the past 75 million years. Nature, 314:526-528.

Parsons, B., and Sclater, J.G., 1977. An analysis of the variation of ocean floor bathymetry and heat flow with age. J. Geophys. Res., 82:803-829.

Quinn, T.M., Lohmann, K.C., and Halliday, A.N., 1991. Sr isotopic variation in shallow water carbonate sequences: stratigraphic, chronostratigraphic, and eustatic implications of the record at Enewetak Atoll. Paleoceanography, 6:371-385.

Sager, W.W., Winterer, E.L., Firth, J.V., et al., 1993. Proc. ODP, Init. Repts., 143: College Station, TX (Ocean Drilling Program).

Winterer, E.L., and Metzler, C.V., 1984. Origin and subsidence of guyots in Mid-Pacific Mountains. J. Geophys. Res., 89:9969-9979.

Winterer, E.L., Natland, J.H., van Waasbergen, R.J., Duncan, R.A., McNutt, M.K., Wolfe, C.J., Premoli Silva, I., Sager, W.W., and Sliter, W.V., 1993. Cretaceous guyots in the Northwest Pacific: an overview of their geology and geophysics. In Pringle, M.S., Sager, W.W., Sliter, W.V., and Stein, S. (Eds.), The Mesozoic Pacific: Geology, Tectonics, and Volcanism. Am. Geophys. Union, Geophys. Monogr., 77:307-334.

Abbreviations for names of organizations and publications in ODP reference lists follow the style given in Chemical Abstracts Service Source Index (published by American Chemical Society).

Date of initial receipt: 22 November 1993

Date of acceptance: 8 April 1994

Ms 143SR-212 
APPENDIX A

Strontium-isotope values determined in this study (Site 866, Resolution Guyot), with accompanying light-isotope and mineralogical data, where available. All data were generated at Oxford University, except in the case of those samples marked with an asterisk, whose strontium-isotope ratios were determined at the University of North Carolina.

\begin{tabular}{|c|c|c|c|c|c|c|c|c|}
\hline $\begin{array}{l}\text { Core, section, } \\
\text { interval }(\mathrm{cm})\end{array}$ & $\begin{array}{l}\text { Depth } \\
\text { (mbsf) }\end{array}$ & ${ }^{87} \mathrm{Sr} /{ }^{86} \mathrm{Sr}$ & $\begin{array}{l}\text { Quoted } \\
\text { error }\end{array}$ & $\delta^{18} \mathrm{O}$ & $\delta^{13} \mathrm{C}$ & Material & Lithology & Mineralogy \\
\hline 3R-CC, 1-2 & 10.21 & 0.707448 & 0.000020 & -2.08 & 3.01 & Limestone & Wackestone & Calcite \\
\hline $7 \mathrm{R}-\mathrm{CC}, 14-15$ & 47.94 & 0.707458 & 0.000024 & -1.48 & 2.43 & Limestone & Wackestone & Calcite \\
\hline 9R-CC, 2-3 & 67.22 & 0.707426 & 0.000020 & -1.69 & 2.50 & Limestone & Wackestone-packstone & Calcite \\
\hline $11 \mathrm{R}-\mathrm{CC}, 9-10$ & 86.59 & 0.707444 & 0.000020 & -1.87 & 2.99 & Limestone & Wackestone & Calcite \\
\hline 13R-CC, $3-4$ & 105.83 & 0.707449 & 0.000020 & -1.72 & 2.95 & Limestone & Wackestone-packstone & Calcite \\
\hline $15 \mathrm{R}-\mathrm{CC}, 2-3$ & 125.02 & 0.707421 & 0.000020 & -1.36 & 2.66 & Limestone & Wackestone & Calcite \\
\hline $17 \mathrm{R}-\mathrm{CC}, 2-3$ & 144.42 & 0.707421 & 0.000021 & -1.56 & 2.58 & Limestone & Packstone-wackestone & Calcite \\
\hline 19R-CC, $7-8$ & 164.87 & 0.707414 & 0.000020 & -2.16 & 2.64 & Limestone & Wackestone & Calcite \\
\hline 22R-CC, $8-9$ & 193.88 & 0.707447 & 0.000024 & -1.53 & 3.05 & Limestone & Wackestone & Calcite \\
\hline $23 \mathrm{R}-\mathrm{CC}, 3-4$ & 203.43 & 0.707450 & 0.000030 & -1.38 & 3.35 & Limestone & Wackestone & Calcite \\
\hline $25 \mathrm{R}-1,61-62$ & 223.31 & 0.707476 & 0.000022 & $\begin{array}{l}-1.50 \\
-1.51\end{array}$ & 2.86 & Limestone & Wackestone & Calcite \\
\hline $28 \mathrm{R}-\mathrm{CC}, 9-11$ & 251.69 & 0.707436 & 0.000031 & $\begin{array}{l}-1.01 \\
-2.04\end{array}$ & 2.58 & Limestone & Grainstone & Calcite \\
\hline $31 \mathrm{R}-1,81-82$ & 281.41 & 0.707429 & 0.000020 & -1.93 & 2.39 & Limestone & Wackestone & Calcite \\
\hline $33 R-C C, 12-13$ & 299.62 & 0.707377 & 0.000020 & -2.33 & 1.83 & Limestone & Wackestone & Calcite \\
\hline $34 \mathrm{R}-\mathrm{CC}, 4-6$ & 309.24 & 0.707384 & 0.000022 & -1.50 & 2.78 & Limestone & Wackestone & Calcite \\
\hline $36 \mathrm{R}-1,27-28$ & 328.77 & 0.707428 & 0.000020 & -1.76 & 2.63 & Limestone & Mudstone & Calcite \\
\hline $37 \mathrm{R}-1,24-26$ & 338.24 & 0.707431 & 0.000020 & -1.64 & 2.81 & Limestone & Mudstone & Calcite \\
\hline $38 \mathrm{R}-1,53-54$ & 343.23 & 0.707395 & 0.000020 & -1.16 & 2.91 & Limestone & Mudstone & Calcite \\
\hline $39 R-2,41-42$ & 349.00 & 0.707322 & 0.000020 & -2.88 & 1.68 & Limestone & Mudstone & Calcite \\
\hline 40R-CC, $1-3$ & 357.31 & 0.707372 & 0.000020 & -1.56 & 2.63 & Limestone & Mudstone-wackestone & Calcite \\
\hline $42 \mathrm{R}-\mathrm{CC}, 7-8$ & 376.67 & 0.707340 & 0.000020 & -1.93 & 2.99 & Limestone & Mudstone-wackestone & Calcite \\
\hline 43R-CC, $21-22$ & 386.51 & 0.707299 & 0.000025 & $\begin{array}{r}-1.95 \\
-1.67\end{array}$ & 3.01 & Limestone & Mudstone-wackestone & Calcite \\
\hline 44R-CC, $7-8$ & 395.97 & 0.707277 & 0.000020 & $\begin{array}{l}-1.07 \\
-2.13\end{array}$ & 2.32 & Limestone & Wackestone-mudstone & Calcite \\
\hline $45 \mathrm{R}-\mathrm{CC}, 38-40$ & 405.98 & 0.707265 & 0.000020 & -1.83 & 3.23 & Limestone & Wackestone & Calcite \\
\hline $47 \mathrm{R}-1,60-62$ & 425.30 & 0.707235 & 0.000020 & -1.52 & 2.77 & Limestone & Mudstone-wackestone & Calcite \\
\hline $48 \mathrm{R}-1,3-5$ & 434.43 & 0.707229 & 0.000020 & -1.89 & 3.14 & Limestone & Wackestone & Calcite \\
\hline $50 \mathrm{R} \mathrm{CC}, 42-44$ & 454.12 & 0.707322 & 0.000020 & $\begin{array}{l}-1.89 \\
-3.12\end{array}$ & $\begin{array}{l}.14 \\
1.88\end{array}$ & Limestone & Packstone & Calcite \\
\hline $53 \mathrm{R}-1,1-5$ & 482.71 & 0.707250 & 0.000023 & -1.87 & 2.54 & Limestone & Grainstone-packstone & Calcite \\
\hline $53 \mathrm{R}-1,41-44(*)$ & 483.11 & 0.707301 & 0.000020 & & & Limestone & Grainstone-packstone & \\
\hline $55 \mathrm{R}-\mathrm{CC}, 18-19$ & 502.08 & 0.707294 & 0.000024 & -2.03 & 1.09 & Limestone & Grainstone-packstone & Calcite \\
\hline $57 \mathrm{R}-1,22-24$ & 521.52 & 0.707295 & 0.000020 & -1.96 & 2.55 & Limestone & Wackestone & Calcite \\
\hline $58 \mathrm{R}-1,12-13$ & 531.12 & 0.707284 & 0.000020 & $\begin{array}{l}-1.90 \\
-1.94\end{array}$ & 2.93 & Limestone & Grainstone-packstone & Calcite \\
\hline $59 \mathrm{R}-1,44-46$ & 541.14 & 0.707314 & 0.000020 & -2.84 & -0.42 & Shell & Shell & Calcite \\
\hline $61 \mathrm{R}-1,68-69$ & 560.58 & 0.707318 & 0.000021 & -2.00 & 3.68 & Limestone & Packstone-grainstone & Calcite \\
\hline $62 \mathrm{R}-1,120-122$ & 570.80 & 0.707325 & 0.000020 & -1.79 & 1.92 & Limestone & Wackestone-grainstone & Calcite \\
\hline $63 \mathrm{R}-1,82-84$ & 580.12 & 0.707355 & 0.000021 & -1.84 & 3.49 & Limestone & Grainstone-packstone & Calcite \\
\hline $64 \mathrm{R}-2,93-95$ & 591.43 & 0.707334 & 0.000020 & -1.71 & 2.83 & Limestone & Wackestone & Calcite \\
\hline $65 R-1,3-6$ & 598.63 & 0.707375 & 0.000024 & -2.28 & 3.38 & Limestone & Wackestone & Calcite \\
\hline $70 R-2,76-80(*)$ & 648.47 & 0.707373 & 0.000020 & & & Limestone & Mudstone-wackestone & \\
\hline $7 \mathrm{IR}-1,12-14(*)$ & 656.50 & 0.707347 & 0.000020 & & & Limestone & Wackestone & \\
\hline $7 \mathrm{IR}-1,10-11$ & 656.60 & 0.707326 & 0.000020 & -1.65 & 5.34 & Limestone & Wackestone & Calcite \\
\hline $71 \mathrm{R}-2,110-112$ & 658.88 & 0.707349 & 0.000020 & -1.65 & 3.40 & Limestone & Packstone & Calcite \\
\hline $73 \mathrm{R}-1,13-16\left({ }^{*}\right)$ & 675.92 & 0.707448 & 0.000020 & & & Limestone & Wackestone-packstone & \\
\hline $73 R-1,72-74$ & 676.52 & 0.707360 & 0.000020 & -1.79 & 4.84 & Limestone & Wackestone-packstone & Calcite \\
\hline $74 \mathrm{R}-3,48-50$ & 688.47 & 0.707553 & 0.000020 & -1.95 & 3.99 & Limestone & Oolitic grainstone-rudstone & Calcite \\
\hline $75 \mathrm{R}-2,94-95$ & 697.19 & 0.707359 & 0.000020 & -2.13 & 4.15 & Limestone & Oolitic grainstone & Calcite \\
\hline $76 \mathrm{R}-1,53-56\left(^{*}\right)$ & 705.23 & 0.707396 & 0.000020 & & & Limestone & Oolitic grainstone & \\
\hline $78 \mathrm{R}-1,99-100$ & 725.09 & 0.707362 & 0.000020 & -2.59 & 4.07 & Limestone & Oolitic-oncolitic grainstone & Calcite \\
\hline $78 \mathrm{R}-2,105-111(*)$ & 726.54 & 0.707413 & 0.000020 & & 4.07 & Limestone & Oolitic-oncolitic grainstone & \\
\hline $79 \mathrm{R}-1,141-143$ & 735.21 & 0.707432 & 0.000020 & -2.21 & 3.97 & Limestone & Oolitic grainstone & Calcite \\
\hline $80 \mathrm{R}-1,90-92$ & 744.40 & 0.707390 & 0.000020 & -1.77 & 4.47 & Limestone & Oolitic-peloidal grainstone & Calcite \\
\hline $81 R-3,30-31$ & 755.38 & 0.707420 & 0.000021 & -1.81 & 4.79 & Limestone & Oolitic grainstone-rudstone & Calcite \\
\hline $82 \mathrm{R}-1,133-135$ & 764.13 & 0.707409 & 0.000020 & $\begin{array}{l}-1.01 \\
-1.78\end{array}$ & 4.85 & Limestone & Oolitic grainstone & Calcite \\
\hline $83 R-1,81-82$ & 773.31 & 0.707478 & 0.000020 & -2.07 & 4.70 & Shell & Oolitic grainstone-packstone & Calcite \\
\hline $84 \mathrm{R}-1,42-45\left(^{*}\right)$ & 782.62 & 0.707395 & 0.000020 & & & Limestone & Oolitic grainstone & \\
\hline $84 \mathrm{R}-1,58-60$ & 782.78 & 0.707419 & 0.000020 & -2.40 & 4.26 & Shell & Oolitic grainstone & Calcite \\
\hline $85 \mathrm{R}-3,13-15$ & 794.88 & 0.707477 & 0.000020 & -1.45 & 2.28 & Limestone & Wackestone & Calcite; trace dolomite \\
\hline $86 \mathrm{R}-1,86-89(*)$ & 802.36 & 0.707459 & 0.000020 & & & Limestone & Packstone-mudstone & \\
\hline $88 \mathrm{R}-1,8-9$ & 820.98 & 0.707407 & 0.000020 & -1.35 & 3.30 & Limestone & Packstone-wackestone & Calcite \\
\hline $89 \mathrm{R}-2,38-39$ & 832.48 & 0.707525 & 0.000020 & $\begin{array}{l}-1.53 \\
-2.23\end{array}$ & 1.06 & Limestone & Mudstone & Calcite \\
\hline $91 \mathrm{R}-1,104-107(*)$ & 850.54 & 0.707504 & 0.000020 & & & Limestone & Peloidal grainstone & \\
\hline $92 \mathrm{R}-1,22-24$ & 859.42 & 0.707460 & 0.000020 & -3.44 & 2.69 & Limestone & Rudistid grainstone & Calcite \\
\hline $94 \mathrm{R}-1,57-60$ & 878.97 & 0.707493 & 0.000020 & -2.67 & 2.66 & Limestone & Grainstone-rudstone & Calcite \\
\hline $96 \mathrm{R}-1,11-13$ & 897.81 & 0.707513 & 0.000020 & -2.38 & 3.48 & Limestone & Packstone-wackestone & Calcite \\
\hline $97 \mathrm{R}-1,33-36\left(^{*}\right)$ & 907.73 & 0.707497 & 0.000020 & & & Limestone & 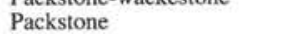 & \\
\hline $98 \mathrm{R}-1,11-16(*)$ & 917.11 & 0.707524 & 0.000020 & & & Limestone & Wackestone & \\
\hline $98 \mathrm{R}-1,20-23$ & 917.20 & 0.707480 & 0.000020 & -1.93 & 3.43 & Limestone & Wackestone & Calcite \\
\hline $99 \mathrm{R}-1,46-49$ & 924.36 & 0.707484 & 0.000020 & -1.91 & 1.11 & Limestone & Wackestone & Calcite \\
\hline $100 \mathrm{R}-1,51-54$ & 933.91 & 0.707531 & 0.000020 & -2.21 & 1.07 & Limestone & Wackestone-mudstone & Calcite \\
\hline $102 \mathrm{R}-1,16-20(*)$ & 952.86 & 0.707495 & 0.000020 & & & Limestone & Grainstone & \\
\hline 104R-1, 81-83 & 972.51 & 0.707509 & 0.000024 & -1.88 & 1.31 & Limestone & Packstone-wackestone & Calcite; minor dolomite \\
\hline $109 R-2,89-91$ & 1021.93 & 0.707508 & 0.000020 & -2.15 & 2.77 & Limestone & Packstone & Calcite \\
\hline $110 \mathrm{R}-1,45-48$ & 1030.05 & 0.707499 & 0.000021 & -2.28 & 2.04 & Limestone & Packstone & Calcite \\
\hline $111 \mathrm{R}-1,30-33$ & 1039.60 & 0.707595 & 0.000020 & -2.29 & 2.15 & Limestone & Packstone & Calcite \\
\hline $112 \mathrm{R}-1,19-21$ & 1049.09 & 0.707501 & 0.000022 & -2.11 & 1.23 & Limestone & Mudstone-wackestone & Calcite; trace dolomite \\
\hline $114 \mathrm{R}-1,59-62$ & 1068.79 & 0.707512 & 0.000020 & -2.00 & 0.88 & Limestone & Wackestone-packstone & Calcite \\
\hline $116 \mathrm{R}-1,22-27(*)$ & 1087.72 & 0.707627 & 0.000020 & & & Limestone & Packstone-grainstone & \\
\hline $117 \mathrm{R}-1,40-43$ & 1097.50 & 0.707517 & 0.000020 & -1.99 & 2.67 & Limestone & Packstone & Calcite \\
\hline $118 \mathrm{R}-1,94-96$ & 1107.74 & 0.707469 & 0.000020 & -1.73 & 1.71 & Limestone & Wackestone & Calcite \\
\hline $120 \mathrm{R}-1,34-38(*)$ & 1126.44 & 0.707502 & 0.000020 & & & Limestone & Peloidal packstone & \\
\hline $121 \mathrm{R}-1,73-75$ & 1136.43 & 0.707486 & 0.000020 & -2.06 & 2.16 & Limestone & Mudstone & Calcite \\
\hline$-1,11-13$ & 45.51 & 0.707528 & 0.000020 & -2.40 & 2.52 & Limestone & Packstone-wackesto & Calcite; m \\
\hline $125 \mathrm{R}-3,76-78$ & 1178.09 & 0.707443 & 0.000020 & -2.78 & 1.83 & Limestone & Peloidal oolitic grai & Calci \\
\hline $129 \mathrm{R}-2,13-15$ & 1214.53 & 0.707498 & 0.000022 & -2.04 & 1.63 & Limestone & Oolitic grainstone & Calcite \\
\hline $132 \mathrm{R}-1,51-53$ & 1242.41 & 0.707533 & 0.000020 & -1.93 & 1.83 & Shell & Rudistid wackestone & Calcite; trace dolomite \\
\hline
\end{tabular}


APPENDIX A (continued).

\begin{tabular}{|c|c|c|c|c|c|c|c|c|}
\hline $\begin{array}{l}\text { Core, section, } \\
\text { interval }(\mathrm{cm})\end{array}$ & $\begin{array}{l}\text { Depth } \\
\text { (mbsf) }\end{array}$ & ${ }^{87} \mathrm{Sr} /{ }^{86} \mathrm{Sr}$ & $\begin{array}{l}\text { Quoted } \\
\text { error }\end{array}$ & $\delta^{18} \mathrm{O}$ & $\delta^{13} \mathrm{C}$ & Material & Lithology & Mineralogy \\
\hline 141R-CC, $14 \cdot 15$ & 1328.74 & 0.707449 & 0.000033 & -0.83 & 2.38 & Limestone & Peloidal packstone & Calcite \\
\hline $142 \mathrm{R}-1,27-28$ & 1338.47 & 0.707573 & 0.000020 & -0.53 & 2.21 & Lmst/Dol & Dolomitic oolitic grainstone & Calcite; dolomite \\
\hline 143R-1, 90-93 (*) & 1348.80 & 0.707524 & 0.000020 & & & Lmst/Dol & Dolomitic oolitic grainstone & \\
\hline $145 \mathrm{R}-2,61-62$ & 1368.91 & 0.707462 & 0.000020 & -1.86 & 1.85 & Limestone & Dolom. grainstone-wackestone & Calcite \\
\hline $150 \mathrm{R}-2,111-114$ & 1417.66 & 0.707478 & 0.000020 & -2.35 & 2.15 & Limestone & Oolitic grainstone & Calcite \\
\hline $153 R-2,54-55$ & 1446.06 & 0.707482 & 0.000020 & -2.57 & 2.33 & Limestone & Oolitic-peloidal grainstone & Calcite; trace dolomite \\
\hline $154 \mathrm{R}-1,110-112$ & 1454.90 & 0.707490 & 0.000020 & -2.39 & 1.88 & Limestone & Dolomitic oolitic grainstone & Calcite : \\
\hline $155 \mathrm{R}-2,58-62$ & 1465.49 & 0.707459 & 0.000020 & -2.64 & 2.05 & Limestone & Oolitic grainstone-rudstone & Calcite; trace dolomite \\
\hline $156 \mathrm{R}-3,70-74(*)$ & 1476.68 & 0.707474 & 0.000020 & & & Limestone & Oolitic grainstone-rudstone & \\
\hline $157 \mathrm{R}-3,41-43$ & 1486.17 & 0.707480 & 0.000020 & -2.88 & 2.37 & Limestone & Oolitic grainstone-rudstone & Calcite \\
\hline $160 \mathrm{R}-1,15-17$ & 1511.85 & 0.707432 & 0.000020 & -3.07 & 2.09 & Limestone & Oncolitic rudstone-grainstone & Calcite \\
\hline $162 \mathrm{R}-1,15-19\left(^{*}\right)$ & 1531.15 & 0.707557 & 0.000020 & & & Dolomite & Dolomite & \\
\hline $166 \mathrm{R}-1,125-127$ & 1570.55 & 0.707437 & 0.000020 & -2.77 & 2.39 & Limestone & Dolomitic oolitic packstone & Calcite; minor dolomite \\
\hline $168 \mathrm{R}-1,40-41$ & 1590.50 & 0.707364 & 0.000020 & -3.00 & 2.21 & Limestone & Dolomitic oolitic grainstone & Calcite; dolomite \\
\hline $169 \mathrm{R}-2,122-123$ & 1602.52 & 0.707271 & 0.000020 & -3.12 & 2.11 & Limestone & Oolitic oncolitic grainstone & Calcite \\
\hline $170 \mathrm{R}-4,68-70$ & 1614.40 & 0.707268 & 0.000020 & -3.23 & 2.04 & Limestone & Oolitic oncolitic grainstone & Calcite \\
\hline
\end{tabular}

APPENDIX B

Strontium-isotope values determined in this study (Site 865, Allison Guyot), with accompanying light-isotope and mineralogical data, where available. All strontium-isotope ratios were determined at University of North Carolina; all other data were generated at Oxford University.

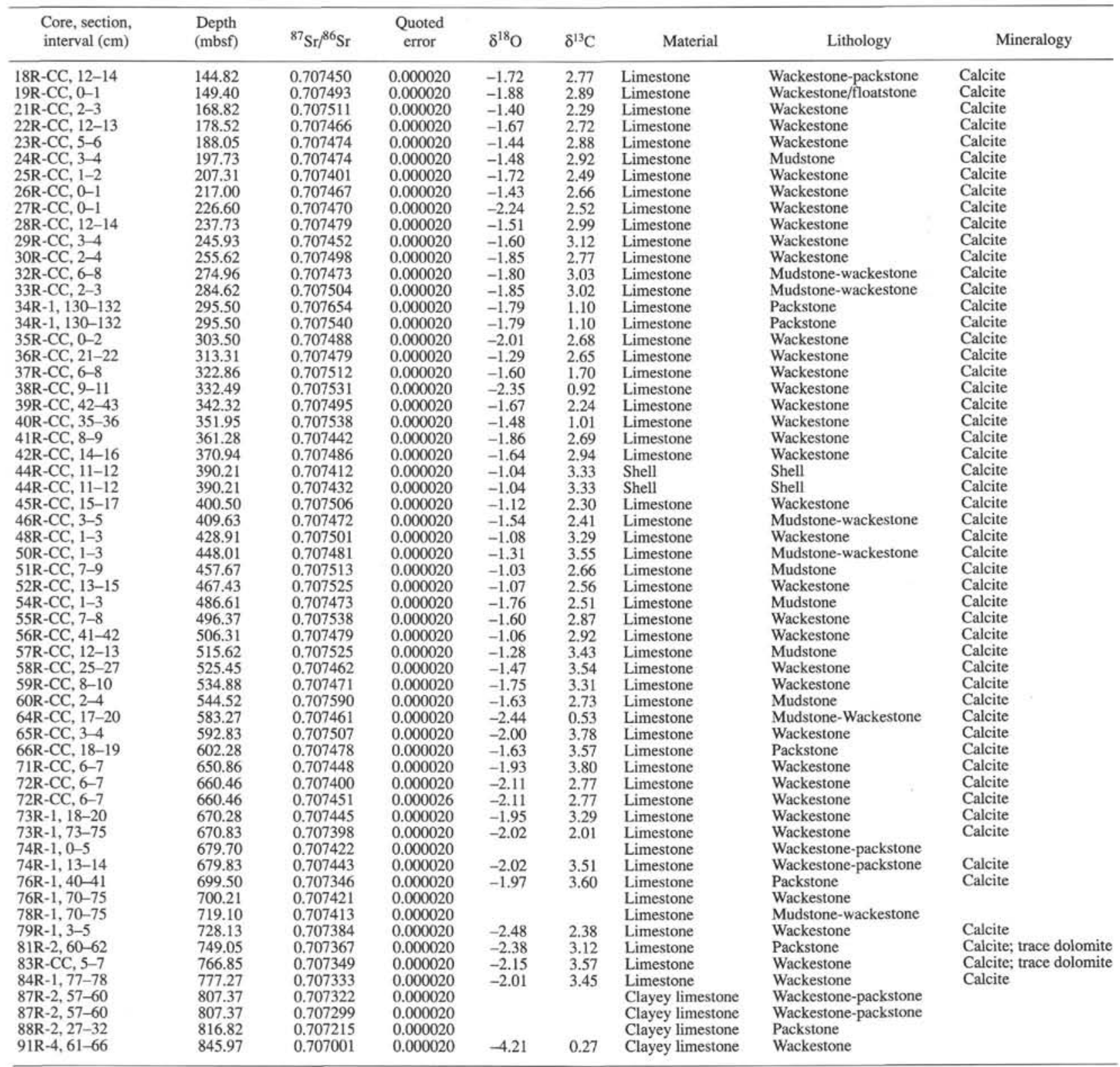

